\title{
High fat diet has a prominent effect upon the course of chronic schistosomiasis mansoni in mice
}

\author{
Alba Cristina Miranda de Barros Alencar', Renata Heisler Neves², Márcia Barbosa Águila ${ }^{3}$, \\ Carlos Alberto Mandarim-de-Lacerda ${ }^{3}$, Delir Corrêa Gomes ${ }^{2}$, José Roberto Machado-Silva ${ }^{1 /+}$
}

${ }^{3}$ Laboratório de Morfometria e Morfologia Cardiovascular, Instituto de Biologia 'Laboratório de Helmintologia Romero Lascasas Porto, Departamento de Microbiologia, Imunologia e Parasitologia, Faculdade de Ciências Médicas, Centro Biomédico, Universidade do Estado do Rio de Janeiro, Rua Prof. Manoel de Abreu 444, 5 andar, 20511- 070 Rio de Janeiro, RJ, Brasil ${ }^{2}$ Laboratório de Helmintos Parasitos de Vertebrados, Instituto Oswaldo Cruz-Fiocruz, Rio de Janeiro, RJ, Brasil

This study investigated whether a long-term high-fat diet has an effect on the outcome of chronic murine schistosomiasis mansoni compared to a standard diet. Swiss Webster female mice (3 weeks old) were fed each diet for up to six months and were then infected with 50 Schistosoma mansoni cercariae. Their nutritional status was assessed by monitoring total serum cholesterol and body mass. Infected mice were examined 6-17 weeks post infection to estimate the number of eggs in faeces. Mice were euthanised the next day. Total serum cholesterol was lower in infected mice in comparison to uninfected controls ( $p=0.0055)$. In contrast, body mass $(p=0.003)$, liver volume $(p=0.0405)$, spleen volume $(p=0.0124)$, lung volume $(p=0.0033)$ and faecal $(p=0.0064)$ and tissue egg density $(p=0.0002)$ were significantly higher for infected mice fed a high-fat diet. From these findings, it is suggested that a high-fat diet has a prominent effect on the course of chronic schistosomiasis mansoni in mice.

Key words: Schistosoma mansoni - cholesterol - chronic phase

The complexity of Schistosoma mansoni growth, migration and development implies that numerous levels of regulation occur as host glucose metabolism and its immune response (Saule et al. 2005, Loverde et al. 2007).

Schistosomes are blood-dwelling flukes that are highly dependent on the host metabolism (Saule et al. 2005). As a result, physiological changes associated with schistosomiasis infection have been considered important factors influencing this host-parasite relationship (Hulstijn et al. 2003). Early studies showed dramatic alterations in adult worm development (Neves et al. 2001, 2002, Oliveira et al. 2003), as well as diminished schistosomal periovular granuloma and milder chronic lesions in undernourished mice compared to mice fed a normal diet (Coutinho et al. 2003).

Animal models have shown reductions in the concentration of lipoproteins in plasma during experimental schistosomiasis mansoni infection (El-Marzouki \& Amin 1997, Muller et al. 2001, Ramos et al. 2004). Furthermore, schistosome infection counteracts the effects of an atherogenic diet by modulating host lipid metabolism and inducing a reduction in total blood cholesterol (Doenhoff et al. 2002). Chronic exposure to schistosome eggs promoted the development of a Th2 response and reduced the levels of total cholesterol and LDL in serum, but it failed to reduce aortic lesion development ( $\mathrm{La}$ Flamme et al. 2007).

Financial support: FAPERJ. MBA, CAML, DCG and JRMS are CNPq research fellows.

+ Corresponding author: jromasilva@yahoo.com.br

Received 26 November 2008

Accepted 4 March 2009
As part of a series of studies being carried out in our laboratories on the role of dyslipidaemia during acute schistosomiasis infection, it was observed that a high-fat diet favours the development of adult worms (Neves et al. 2007a). Moreover, egg maturity, faecal output, viability and egg hatching were higher compared to mice fed a standard diet (Neves et al. 2007b). The purpose of this study was to determine whether a high-fat diet could alter the outcome of chronic schistosomiasis.

\section{MATERIALS AND METHODS}

The study design reported herein complies with the current laws regarding ethical procedures involving laboratory animals and was approved by Comissão de Ética de Uso de Animais-Fiocruz (L-0036/07), Rio de Janeiro, Brazil.

Animals and housing - Weanling (21 day) Swiss Webster female mice (Centro de Criação de Animais de Laboratório-Fiocruz) were housed conventionally in polypropylene cages $(40 \times 33 \mathrm{~cm})$ with stainless steelscreened covers. Mice were kept in a temperature $(21 \pm$ $\left.1^{\circ} \mathrm{C}\right)$ and humidity-controlled $(60 \pm 10 \%)$ room and exposed to a $12 \mathrm{~h}$ light/dark cycle with artificial lights and to an air exhaustion cycle.

Diet - Experimental animals were fed their specific diets from weaning at the age of 21 days. Hypercholesterolaemia was induced by feeding high-fat chow (HFC) composed of pork lard, egg yolks, wheat flour, corn starch, casein and balanced with vitamins and minerals (47\% carbohydrates, 24\% proteins, 29\% lipids) $(5.7$ $\mathrm{kcal} / \mathrm{g}$ body wt/day) (Neves et al. 2006) for more than a period of six months after weaning. Control groups were fed standard lab chow (SC) for mice (Nuvilab CR1-NUVITAL Nutrients Ltda., Colombo, Paraná, Brazil) 
containing $12 \%$ fat, $28 \%$ protein and $60 \%$ carbohydrate ( $4.6 \mathrm{kcal} / \mathrm{g}$ body wt/day). Animals were weighed twice a week throughout the experiment. All animals were given free access to water and food during the study.

Experimental infection protocol - After six months of feeding on their respective diets, 20 mice were each subcutaneously infected with $\sim 50$ S. mansoni (BH strain) cercariae recovered by shedding from laboratory-reared Biomphalaria glabrata snails (Martinez et al. 2003). The $S$. mansoni life cycle has been maintained at the Laboratório de Malacologia (Instituto Oswaldo Cruz-Fiocruz), using B. glabrata snails and mice for the past 40 years.

A total of 30 mice were separated into four groups: $(\mathrm{SC})(\mathrm{n}=5)$, uninfected mice fed HFC $(\mathrm{n}=5)$, infected mice fed standard chow (ISC) $(\mathrm{n}=10)$ and infected mice fed (IHFC) $(\mathrm{n}=10)$.

Biochemical assay - After the 6-month feeding period, total serum cholesterol was assayed using the colorimetric enzymatic method as previously described (Neves et al. 2006). Briefly, plasma was obtained from blood samples collected from food-deprived mice (overnight) by puncture of the retro orbital sinus. The biochemical assay was conducted both the day before experimental infection and at necropsy 17 weeks post infection, when mice were euthanised by jugular section (hypovolaemic shock). The blood was centrifuged at $1200 \mathrm{~g}$ for $15 \mathrm{~min}$ at $\mathrm{rt}$ to separate the serum, which was stored at $-20^{\circ} \mathrm{C}$ until use.

Biometry - Body mass was evaluated at two points throughout the experiment: weeks zero and 36.

Parasitologic examination - Susceptibility to infection was evaluated by quantifying faecal egg excretion 6-17 weeks post-infection. The faeces were analysed in duplicate by the Kato-Katz technique processed in order to determine the number of eggs per gram of stool. The percentage of viable eggs in stool samples was determined by a quantitative sedimentation. The viability of these eggs was determined by flame cell activity and/ or movement in miracidium. The prepatent period was determined by when the first faecal eggs were found (Martinez et al. 2003).

Euthanasia - Mice were euthanised the day after the last faecal examination was performed. Skin was opened by a midline incision in the thorax and abdomen to remove liver, intestine and spleen. Liver volume, intestine volume (IV) and spleen volume (SV) were determined by the Scherle liquid displacement method (Scherle 1970).

Adult worms were recovered from the portal system and mesenteric veins. The rate of infection (infectivity) was calculated as the percentage of maturation of cercariae into adult worms (Freire et al. 2003). For the enumeration of eggs, the liver and small intestine were removed from freshly killed mice. The organs were digested in $4 \%$ potassium hydroxide at $56^{\circ} \mathrm{C}$ and centrifuged $(900 \mathrm{~g})$ for $5 \mathrm{~min}$. For oogram performance, duplicate $100 \mu \mathrm{L}$ aliquots of the digest were placed on a glass slide and eggs were counted by light microscopy (100X) (Martinez et al. 2003).

Statistical analysis - Data were statically analyzed using the SPSS software. The Mann-Whitney and Student's $t$-test were used to assess the total cholesterol, body mass index at week zero of experiment, infectivity and faeces eggs total were compared between IHFC and ISC groups. The analysis of variance (One Way Anova) was used to estimate the body mass and organs volume in different weeks of experiment. The Person's correlation test was used to assess the correlation between the number of eggs passed in faeces and worm burden between IHFC and ISC mice. A p-value $\leq 0.05$ was considered significant (Vieira 1991).

\section{RESULTS}

Three IHFC mice and one ISC mouse died during the experiment.

Biochemical analysis - As shown in Table I, mice fed the high-fat diet showed significantly increased total cholesterol levels both before $(p=0.0003)$ and after $(p$ $=0.001)$ infection.

Biometry analysis - There was a significant difference $(p=0.0003)$ in the gain of body mass between mice fed each diet for 36 weeks. Mice fed the high-fat diet gained more body mass [HFC $(58 \pm 9)$ and IHFC $(59 \pm 12)]$ than standard controls [SC $(43 \pm 2)$ and ISC $(39 \pm 4)]$ (Table II).

Significantly greater liver $(3.1 \pm 0.6, \mathrm{p}=0.0031)$ and SVs $(0.9 \pm 0.7, p=0.0039)$ were observed for IHFC the lipid-rich diet (Table II). IV decreased in the HFC group $(4.0 \pm 1.2, p=0.0034)$ when compared to the SC group.

Parasitologic examination - Table II shows that the high-fat diet resulted in significantly $(\mathrm{p}=0.0001)$ higher infectivity (22\%) than the standard diet (14\%). The male/ female sex-ratio was 1.1:1 in the IHFC group and 1.2:1 in the ISC group. The mean prepatent period was $49 \pm$ 1 days, irrespective of diet. High-fat feeding resulted in a higher total egg output in the IHFC group (61.056) in comparison to the ISC group (18.144) $(\mathrm{p}=0.0064)$. The densities of the eggs in the intestine $(25.236 \pm 7.516 ; 4621$ $\pm 2.942, \mathrm{p}=0.0002)$ and liver $(10.804 \pm 2828 ; 2606 \pm$ $1.330, p=0.0002$ ) were statistically greater in the IHFC group than in the ISC group. Table II also shows that egg viability was higher in the IHFC group $(4 \pm 0.9)$ compared to the ISC group $(2 \pm 0.8)(\mathrm{p}=0.0276)$.

The pattern of egg production in the faeces is illustrated in Fig. 1. There was an initial rise in the egg output of the mice fed the high-fat diet by weeks 8-10. During the following counts, an irregular excretion was observed, with marked increases (week 13) and decreases (week 14). In the later stages of the infection, there was a tendency for high egg excretion. Despite the fact that mice fed a standard diet produced lower egg counts, weekly variations were less pronounced. In contrast to the other group, at the end of the observation period the egg count dropped rapidly $(\mathrm{p}<0.05)$.

The relationship between the number of eggs passed in the faeces and worm burden in both groups was adequately described by a linear regression model. There was no significant correlation (Fig. 2A) in the IHFC group $(r=0.5264, p=0.2248)$; however, there was a significant correlation (Fig. 2B) in the ISC group between egg count and worm pairs $(\mathrm{r}=0.9943, \mathrm{p}=0.0001)$. 
TABLE I

Biochemical and biometrical findings in schistosomiasis-infected SW mice fed high-fat chow or standard chow

\begin{tabular}{lccccr}
\hline & \multicolumn{3}{c}{ Groups } & \\
\cline { 2 - 5 } Parameters & HFC & IHFC & SC & ISC & P values \\
\hline $\mathrm{TC}^{c}(\mathrm{mmol} / \mathrm{L})$ & $1.6 \pm 0.3$ & - & $1.0 \pm 0.2$ & - & 0.0080 \\
$\mathrm{TC}^{b}(\mathrm{mmol} / \mathrm{L})$ & $1.2 \pm 0.1$ & $1.2 \pm 0.3$ & $0.7 \pm 0.2$ & $0.9 \pm 0.2$ & 0.0055 \\
$\mathrm{BM}^{0}(\mathrm{~g} / \mathrm{cm})$ & $14 \pm 2.5$ & - & $15 \pm 2$ & - & 0.2034 \\
$\mathrm{BM}^{36}(\mathrm{~g} / \mathrm{cm})$ & $58 \pm 9$ & $59 \pm 12$ & $43 \pm 2$ & $39 \pm 4$ & 0.0003 \\
$\mathrm{BM}^{49}(\mathrm{~g} / \mathrm{cm})$ & $58 \pm 9$ & $50 \pm 7$ & $55 \pm 6$ & $44 \pm 6$ & 0.0347 \\
$\mathrm{LV}^{\diamond}\left(10^{3} \mathrm{~mm}^{3}\right)$ & $2.3 \pm 0.9$ & $3.0 \pm 0.5$ & $2.2 \pm 0.2$ & $2.4 \pm 0.5$ & 0.0405 \\
$\mathrm{IV}^{\diamond}\left(10^{3} \mathrm{~mm}^{3}\right)$ & $4.0 \pm 1.1$ & $6.0 \pm 1.5$ & $6.7 \pm 1.1$ & $5.9 \pm 1.0$ & 0.0034 \\
$\mathrm{SV}^{\diamond}\left(10^{3} \mathrm{~mm}^{3}\right)$ & $0.3 \pm 0.2$ & $0.8 \pm 0.6$ & $0.2 \pm 0.1$ & $0.3 \pm 0.1$ & 0.0124 \\
$\mathrm{HV}^{\diamond}\left(10^{3} \mathrm{~mm}^{3}\right)$ & $0.2 \pm 0.0$ & $0.1 \pm 0.04$ & $0.1 \pm 0.02$ & $0.1 \pm 0.05$ & 0.0039 \\
$\mathrm{LuV}^{\diamond}\left(10^{3} \mathrm{~mm}^{3}\right)$ & $0.2 \pm 0.1$ & $0.5 \pm 0.2$ & $0.2 \pm 0.07$ & $0.3 \pm 0.1$ & 0.0033 \\
$\mathrm{KV}^{\diamond}\left(10^{3} \mathrm{~mm}^{3}\right)$ & $0.7 \pm 0.2$ & $0.6 \pm 0.08$ & $0.4 \pm 0.1$ & $0.5 \pm 0.1$ & 0.0212 \\
\hline
\end{tabular}

values are the mean \pm standard deviation, used statics test: Test $\mathrm{T}\left(\mathrm{TC}^{a}\right.$ and $\left.\mathrm{BM}^{0}\right)$ and Anova (others parameters). Significant differences $(\mathrm{p}<0.05)$. $a$ : after 41 weeks of experiment; $b$ : after 50 weeks of experiment; $\mathrm{BM}^{0}, \mathrm{BM}^{36}, \mathrm{BM}^{49}$ : body mass index after 0,36 and 49 weeks of experiment, respectively; $c$ : when compared with the respective control group; HFC: uninfected mice fed high-fat diet; HV: heart volume; IHFC: infected mice fed high-fat chow diet; ISC: infected mice fed standard chow; IV: intestine volume; KV: kidney volume; LuV: lung volume; LV: liver volume; SC: uninfected mice fed standard chow; SV: spleen volume; TC: total cholesterol serum concentration; $\diamond$ : organs volume (Scherle's method) after 49 weeks of experiment and 17 weeks post infection.

\section{TABLE II}

Parasitologic findings in Swiss mice fed high-fat diet or standard chow, during the course of chronic phase of schistosomiasis

\begin{tabular}{lccc}
\hline & \multicolumn{2}{c}{ Groups } & \\
\cline { 2 - 3 } Parameters & IHFC $(\mathrm{n}=7)$ & ISC $(\mathrm{n}=9)$ & $\mathrm{p}$ values \\
\hline Infectivity & $22 \%$ & $14 \%$ & 0.0001 \\
Faeces eggs (total) & 61056 & 18144 & 0.0064 \\
Intestine egg count & $25236 \pm 7516$ & $4621 \pm 2942$ & 0.0002 \\
Liver egg count & $10804 \pm 2828$ & $2606 \pm 1330$ & 0.0002 \\
Egg viability & $4 \pm 0.9$ & $2 \pm 0.8$ & 0.0276 \\
\hline
\end{tabular}

values are the mean \pm standard deviation. Mice were euthanised 17 weeks pi. IHFC: infected mice fed high-fat chow diet; ISC: infected mice fed standard chow.

\section{TABLE III}

Effects of a high-fat diet on parasitologic aspects in Swiss mice chronically infected with Schistosoma mansoni

\begin{tabular}{lccc}
\hline & \multicolumn{2}{c}{ Groups } & \\
\cline { 2 - 3 } Parameters & IHFC $(\mathrm{n}=7)$ & ISC $(\mathrm{n}=9)$ & $\mathrm{p}$ values \\
\hline Infectivity & $22 \%$ & $14 \%$ & 0.0001 \\
Faecal eggs (total) & 61056 & 18144 & 0.0064 \\
Intestine egg count & $25236 \pm 7516$ & $4621 \pm 2942$ & 0.0002 \\
Liver egg count & $10804 \pm 2828$ & $2606 \pm 1330$ & 0.0002 \\
Egg viability & $4 \pm 0.9$ & $2 \pm 0.8$ & 0.0276 \\
\hline
\end{tabular}

values are the mean \pm standard deviation. Mice were euthanised 17 weeks pi. IHFC: infected mice fed high-fat chow diet; ISC: infected mice fed standard chow.

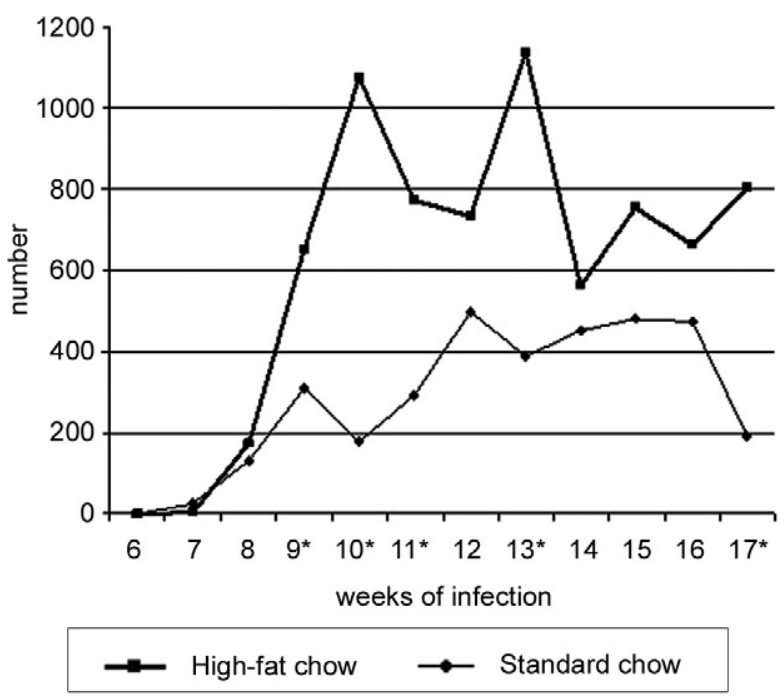

Fig. 1: variation in Schistosoma mansoni egg counts in mice fed high-fat chow or standard chow. Different superscript symbols denote for significant differences between groups analyzed by Mann Whitney $(\mathrm{p}<0.05)$.

\section{DISCUSSION}

Over the last several years, the effects of metabolic disorders on the pathophysiological features of schistosomiasis have indicated that nutrient deprivation leads to a hostile microenvironment for adult worms (Ferreira \& Coutinho 1999, Neves et al. 2002, Simões et al. 2002, Oliveira et al. 2003), as undernourished mice develop milder chronic lesions than normally fed mice (Coutinho et al. 2003). In contrast, a cholesterol-rich environment provides favourable conditions that ensure the reproduc- 
A
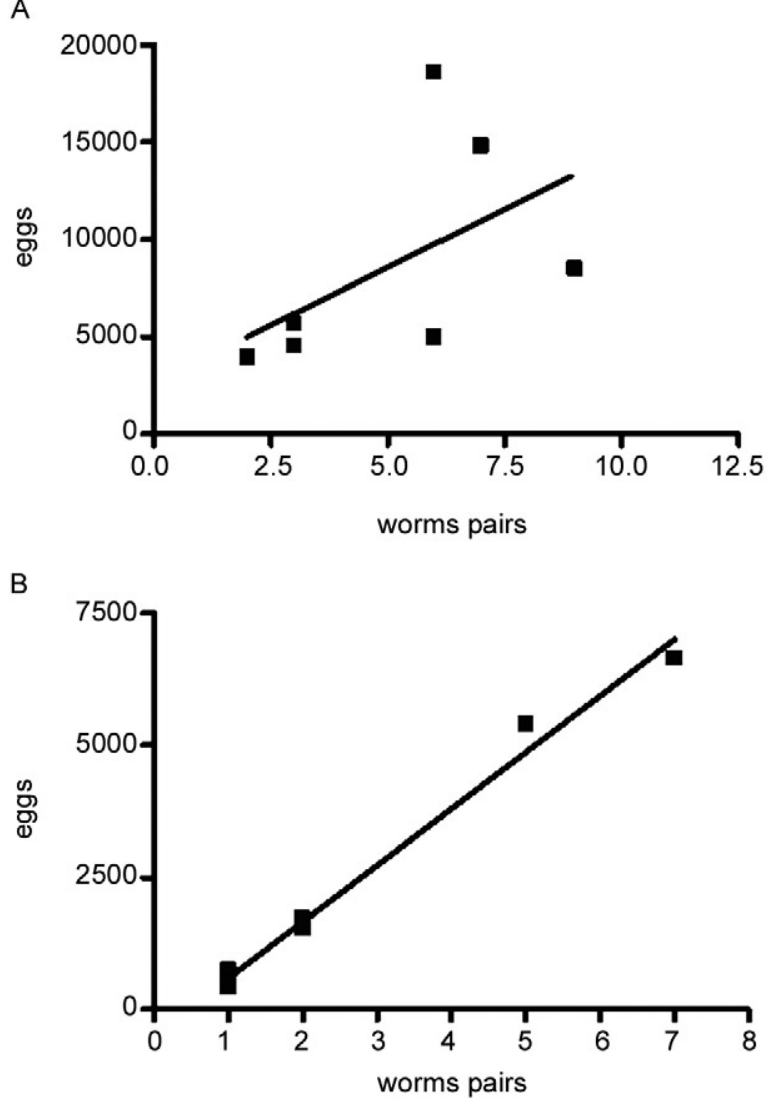

Fig. 2: correlation between the number of Schistosoma mansoni eggs passed in faeces and the number of worm pairs recovered from mice fed high-fat diet (A) or standard diet (B). Data were analyzed by regression and linear correlation tests.

tive success of adult worms, altering the outcome of the acute schistosomiasis infection (Neves et al. 2007b). The present study investigated whether a high-fat diet has any influence on the outcome of chronic schistosomiasis. Our findings highlight some major points which deserve special comment: hypercholesterolaemia does indeed play a major role in tissue damage (Scheuer et al. 2000) and the morbidity observed in schistosomiasis is essentially linked to granulomas around parasite eggs (Pearce et al. 1996).

The high-fat diet induced dyslipidaemia in mice and total cholesterol levels were higher in this group before infection when compared to those receiving the normal diet (Neves et al. 2007b). In addition, after infection, total cholesterol level decreased; however, it remained higher than in mice fed the control diet. Thus, it is possible that an association between high-fat intake and schistosomiasis leads to the acceleration and progression of liver injury (Neves et al. 2006). During the adult phase, mice fed a high-fat diet gained more body mass than mice fed the standard diet. This occurred independent of infection.

Of paramount importance is the observation that hepatosplenomegaly was a marked finding in high-fat diet infected mice. Indeed, the number of hepatic eggs was greater in the IHFC group than in the ISC group. The significance of these increased numbers may be related to granuloma-mediated organ damage of the liver and spleen (Henderson et al. 1993) or to liver changes (venous congestion) with repercussions in splenic structure and function (Andrade et al. 1998). However, spleen enlargements via sinusoidal dilatation and intra or intercellular deposits have also been described in a murine model fed a high-fat diet (Altunkaynak et al. 2007). The mechanistic details relating hypercholesterolaemia and schistosomiasis have remained somewhat elusive until recently. In this scenario, schistosome infections counteract the effects of an atherogenic diet by modulating host lipid metabolism and inducing a reduction in total blood cholesterol (Doenhoff et al. 2002). The chronic exposure to schistosome eggs promoted the development of a Th2 response and also reduced the levels of total cholesterol in the serum, but it failed to reduce aortic lesion development (La Flamme et al. 2007).

The ability to adapt metabolic processes to environmental changes markedly influences the behaviour of schistosomes within the host due to a number of interesting nutritional adaptations (Halton 1997). In the present study, the IHFC group showed higher worm burden, tissue egg, egg viability and egg-laying. These data suggest that schistosomes are closely associated with the modulation of host lipid metabolism (El Ridi et al. 2004, Tallima \& El Ridi 2005). The most plausible explanation is the presence of signalling pathways by which parasites detect host signals and respond to them in a way that presumably both increases their survival (Loverde et al. 2007) and reproduction of adult worms (Neves et al. 2007a). In this study, regression and linear correlation between faecal eggs and worm pairs found no correlation in the IHFC group. This suggests that although higher egg elimination does not correlate with worm pairs, another factor must account for the mechanism of egg production. Perhaps serum cholesterol induces higher egg production during egg embryogenesis among females from mice chronically infected and fed a high-fat diet, which is in line with our previous report (Neves et al. 2007a).

Paired schistosomes migrate toward mesenteric veins, where immature eggs are released. A proportion of these eggs is carried out by the portal flow back to the liver, while other reaches the lumen and are voided with faeces to the external environment (Neves et al. 2007a). Two mechanisms seem to favour their excretion to the outside environment. First, eggs incorporate external nutrients and growth factors as development takes place. Second, molecules secreted from eggs (Ashton et al. 2001) induce cytokine production (Brindley 2005) and local granulomatous inflammation, where inflammatory cells sustain egg passage (Lenzi et al. 1987). Moreover, both structural and functional changes are present during chronic murine schistosomiasis (Moreels et al. 2001). In a previous study, it was hypothesised that lipid-rich diets may be environmental modifiers which lead to exchanges between miracidium inside eggs and nutrients, primarily in the small intestine (Neves et al. 2007b).

As in other studies, mice fed a standard diet excreted few eggs by weeks 6-8 and this count then rose to a peak at week 12 and achieved stability between weeks 13-16, declining thereafter (Rocha et al. 1995, El Ridi et al. 2004). 
In mice fed a high-fat diet, an initial low elimination was observed between 6-8 weeks, followed by significant increases at weeks 9 and 10 , with week-to-week fluctuations from week 11-16, when excretion was increased. The main differences were the absence of stability and a progressive decrease, as previously reported during the chronic phase of schistosomiasis (Cheever et al. 1994, Rocha et al. 1995, Barth et al. 1996). This study complements the existing literature (Neves et al. 2007a, b) indicating that certain dietary patterns may be important for the outcome of chronic schistosomiasis. Altogether, these observations suggest that schistosome infection in mice fed high-fat diets may be a useful tool for understating the consequences for human populations living in areas where both morbidities exist.

\section{ACKNOWLEDGEMENTS}

To Dra. Lygia Reis Corrêa, from the Laboratório de Malacologia do Instituto Oswaldo Cruz, for providing cercariae.

\section{REFERENCES}

Altunkaynak BZ, Ozbek E, Altunkaynak ME 2007. A stereological and histological analysis of spleen on obese female rats, fed with high fat diet. Saudi Med J 28: 353-357.

Andrade ZA, Silva LM, de Souza MM, Sadigursky M, Barbosa A Jr, Oliveira IR 1998. Role of the spleen on the pathogenesis of schistosomal periportal (pipestem) fibrosis of the liver: an experimental approach. Am J Trop Med Hyg 59: 557-562.

Ashton PD, Harrop R, Shah B, Wilson RA 2001. The schistosome egg: development and secretions. Parasitology 122: 329-338.

Barth LR, Fernandes AP, Rodrigues V 1996. Oviposition by Schistosoma mansoni during in vitro cultivation. Rev Inst Med Trop Sao Paulo 38: 423-426.

Brindley PJ 2005. The molecular biology of schistosomes. Trends Parasitol 21: 533-536.

Cheever AW, Macedonia JG, Mosimann JE, Cheever EA 1994. Kinetics of egg production and egg excretion by Schistosoma mansoni and $S$. japonicum in mice infected with a single pair of worms. Am J Trop Med Hyg 50: 281-295.

Coutinho EM, Barros AF, Barbosa A Jr, Oliveira SA, Silva LM, Araujo RE, Andrade ZA 2003. Host nutritional status as a contributory factor to the remodeling of schistosomal hepatic fibrosis. Mem Inst Oswaldo Cruz 98: 919-925.

Doenhoff MJ, Stanley RG, Griffiths K, Jackson CL 2002. An antiatherogenic effect of Schistosoma mansoni infections in mice associated with a parasite-induced lowering of blood total cholesterol. Parasitology 125: 415-421.

El-Marzouki ZM, Amin AM 1997. Changes in serum lipids of mice experimentally infected with Schistosoma mansoni. J Egypt Soc Parasitol 27: 419-429.

El Ridi R, Tallima H, Mohamed SH, Montash M 2004. Depletion of Schistosoma mansoni lung-stage schistosomula cholesterol by methyl-beta-cyclodextrin dramatically increases specific antibody binding to surface membrane antigens. J Parasitol 90: 727-732.

Ferreira HS, Coutinho EM 1999. Should nutrition be considered as a supplementary measure in schistosomiasis control? Ann Trop Med Parasitol 93: 437-447.

Freire N, Rodrigues-Silva R, Machado-Silva JR, Rey L 2003. A comparative parasitologic study on Biomphalaria glabrata snail and
$\mathrm{C} 3 \mathrm{H} / \mathrm{He}$ mice infected with human and murine isolates of Schistosoma mansoni derived from Sumidouro, Rio de Janeiro, Brazil. Mem Inst Oswaldo Cruz 98: 783-787.

Halton DW 1997. Nutritional adaptations to parasitism within the platyhelminthes. Int J Parasitol 27: 693-704.

Henderson GS, Nix NA, Montesano MA, Gold D, Freeman GL Jr, McCurley TL, Colley DG 1993. Two distinct pathological syndromes in male CBA/J inbred mice with chronic Schistosoma mansoni infections. Am J Pathol 142: 703-714.

Hulstijn M, Barros LA, Neves RH, Moura EG, Machado-Silva JR 2003. Morphological changes in the reproductive organs of male and female Schistosoma mansoni worms caused by streptozotocin, a drug used to induce diabetes mellitus. Parasitology 126: 53-61.

La Flamme AC, Harvie M, Kenwright D, Cameron K, Rawlence N, Low YS, McKenzie S 2007. Chronic exposure to schistosome eggs reduces serum cholesterol but has no effect on atherosclerotic lesion development. Parasite Immunol 29: 259-266.

Lenzi HL, Lenzi JA, Sobral AC 1987. Eosinophils favor the passage of eggs to the intestinal lumen in schistosomiasis. Braz J Med Biol Res 20: 433-435.

Loverde PT, Osman A, Hinck A 2007. Schistosoma mansoni: TGFbeta signaling pathways. Exp Parasitol 117: 304-317.

Martinez EM, Neves RH, de Oliveira RM, Machado-Silva JR, Rey L 2003. Parasitological and morphological characteristics of Brazilian strains of Schistosoma mansoni in Mus musculus. Rev Soc Bras Med Trop 36: 557-564.

Moreels TG, De Man JG, Bogers JJ, De Winter BY, Vrolix G, Herman AG, Van Marck EA, Pelckmans PA 2001. Effect of Schistosoma mansoni-induced granulomatous inflammation on murine gastrointestinal motility. Am J Physiol Gastrointest Liver Physiol 280: G1030-1042.

Muller E, Rosa Brunet L, Fried B, Sherma J 2001. Effects on the neutral lipid contents of the liver, ileum and serum during experimental schistosomiasis. Int J Parasitol 31: 285-287.

Neves RH, Alencar ACMB, Águila MB, Mandarim-de-Lacerda CA, Machado-Silva JR, Gomes DC 2006. Somatic, biochemical and hepatic alterations in wild type mice chronically fed high fat diet. Int J Morphol 24: 625-632.

Neves RH, Alencar ACMB, Aguila MB, Mandarim-de-Lacerda CA, Machado-Silva JR, Gomes DC 2007a. Light and confocal microscopic observations of adult Schistosoma mansoni from mice fed on a high-fat diet. $J$ Helminthol 81: 361-368.

Neves RH, Alencar ACMB, Costa-Silva M, Aguila MB, Mandarimde-Lacerda CA, Machado-Silva JR, Gomes DC 2007b. Longterm feeding a high-fat diet causes histological and parasitological effects on murine schistosomiasis mansoni outcome. Exp Parasitol 115: 324-332.

Neves RH, Machado-Silva JR, Pelajo-Machado M, Oliveira SA, Coutinho EM, Lenzi HL, Gomes DC 2001. Morphological aspects of Schistosoma mansoni adult worms isolated from nourished and undernourished mice: a comparative analysis by confocal laser scanning microscopy. Mem Inst Oswaldo Cruz 96: 1013-1016.

Neves RH, Oliveira SA, Machado-Silva JR, Coutinho E, Gomes DC 2002. Phenotypic characterization of Schistosoma mansoni adult worms recovered from undernourished mice: a morphometric study focusing on the reproductive system. Rev Soc Bras Med Trop 35: 405-407.

Oliveira SA, Barbosa AA, Gomes DC, Machado-Silva JR, Barros AF, Neves RH, Coutinho EM 2003. Morphometric study of Schisto- 
soma mansoni adult worms recovered from undernourished infected mice. Mem Inst Oswaldo Cruz 98: 623-627.

Pearce EJ, Cheever A, Leonard S, Covalesky M, Fernandez-Botran R, Kohler G, Kopf M 1996. Schistosoma mansoni in IL-4-deficient mice. Int Immunol 8: 435-444.

Ramos TM, Vasconcelos AS, de Carvalho VC, Lima VL 2004. Alterations in cholesterol, triglyceride and total phospholipid levels in plasma of Callithrix jacchus (sagui) reinfected by Schistosoma mansoni. Rev Soc Bras Med Trop 37: 37-40.

Rocha RL, Rocha MO, Pedroso ER, Colosimo EA, Coelho PM 1995. Egg excretion in the initial phase of experimental murine schistosomiasis mansoni: stability and association with worm burden. Rev Inst Med Trop Sao Paulo 37: 325-329.

Saule P, Vicogne J, Delacre M, Macia L, Tailleux A, Dissous C, Auriault C, Wolowczuk I 2005. Host glucose metabolism mediates T4 and IL-7 action on Schistosoma mansoni development. J Parasitol 91: 737-744.
Scheuer H, Gwinne W, Hohbach J, Grone EF, Brandes RP, Malle E, Olbricht CJ, Walli AK, Grone HJ 2000. Oxidant stress in hyperlipidemia-induced renal damage. Am J Physiol Renal Physiol 278: F63-F74.

Scherle W 1970. A simple method for volumetry of organs in quantitative stereology. Mikroskopie 26: 57-60.

Simões C, Neves RH, Barros LA, Brito PD, Cravo CO, de Moura EG, Machado-Silva JR 2002. Parasitological characteristics of Schistosoma mansoni infection in swiss mice with underlying malnutrition. Mem Inst Oswaldo Cruz 97 (Suppl. I): 143-147.

Tallima H, El Ridi R 2005. Methyl-beta-Cyclodextrin treatment and filipin staining reveal the role of cholesterol in surface membrane antigen sequestration of Schistosoma mansoni and S. haematobium lung-stage larvae. J Parasitol 91: 720-725.

Vieira S 1991. Introdução à bioestatística, Campus, Rio de Janeiro, $196 \mathrm{pp}$. 